\title{
Cystic echinococcosis in Poland: genetic variability and the first record of Echinococcus granulosus sensu stricto (G1 genotype) in the country
}

\author{
Ruslan Salamatin $^{1,2}$ (D) Jerzy Kowal ${ }^{3} \cdot$ Pawel Nosal $^{3} \cdot$ Slawomir Kornaś $^{3}$. \\ Danuta Cielecka $^{1}$ - Dawid Jańczak ${ }^{2}$ - Waldemar Patkowski ${ }^{4}$. Jakub Gawor ${ }^{5}$. \\ Vadim Kornyushin $^{6} \cdot$ Elzbieta Golab $^{2} \cdot$ Viliam Šnábel $^{7}$
}

Received: 1 August 2017 / Accepted: 15 September 2017 / Published online: 3 October 2017

(C) The Author(s) 2017. This article is an open access publication

\begin{abstract}
Cystic echinococcosis is one of the most important zoonotic diseases affecting humans and livestock worldwide, and is endemic in Poland. A set of six isolates on larval stages of Echinococcus granulosus sensu lato tapeworms collected from three humans, two pigs and one sheep from Polish foci of CE was examined by DNA sequencing of two mitochondrial genes $(\operatorname{coxl}, \mathrm{rrnS})$. The results demonstrated the presence of E. canadensis and E. granulosus sensu stricto in the investigated hydatid cysts. The former species was found in all five isolates from pigs and humans derived from central Poland. In a sheep hydatid cyst originating from Lesser Poland Voivodeship in southern Poland, E. granulosus s. s. (G1 genotype) was identified. This is the first report of an unambiguously autochthonous infection with E. granulosus
\end{abstract}

Rusłan Sałamatin

rsalamatin@gmail.com

1 Department of General Biology and Parasitology, Medical University of Warsaw, Chałubińskiego 5, 02-004 Warsaw, Poland

2 Department of Parasitology, National Institute of Public Health National Institute of Hygiene, Chocimska 24, 00-791 Warsaw, Poland

3 Department of Zoology and Ecology, Faculty of Animal Sciences, University of Agriculture in Krakow, al. Mickiewicza 24/28, 30-059 Krakow, Poland

4 Department of General, Transplant and Liver Surgery, Medical University of Warsaw, Banacha 1a, 02-097 Warsaw, Poland

5 W. Stefański Institute of Parasitology, Polish Academy of Sciences, Twarda 51/55, 00-818 Warsaw, Poland

6 I. I. Schmalhausen Institute of Zoology, National Academy of Sciences of Ukraine, Khmelnytskoho 15, Kyiv 01601, Ukraine

7 Institute of Parasitology, Slovak Academy of Sciences, Hlinkova 3, 04001 Košice, Slovakia s. s. in Poland. The global distribution and host affiliations of the commonly occurring G1 microvariant with nucleotide change 56C/T in coxl, detected here in Polish sheep, are discussed. The finding that sheep harboured E. granulosus s. s. may have important consequences for developing effective hydatid control programmes in Poland due to its longer maturation rate in dogs compared with E. canadensis G7. This may lead to greater expenditures for purchasing anthelmintics to provide an appropriate dosing regime in sheep-raising areas of the country.

Keywords Echinococcus granulosus · Poland · DNA sequencing $\cdot$ Genotype $\cdot$ Sheep $\cdot$ Human $\cdot$ Pig

\section{Introduction}

The larval stages of the tapeworm Echinococcus granulosus sensu lato are the causative agent of cystic echinococcosis (CE), one of the most important cestode infections causing morbidity and mortality in humans and significant economic losses in livestock. Around one million or more people are currently suffering from CE globally, and the financial burden of the disease on the livestock industry is substantial, with up to $\$ 2$ billion lost annually (Torgerson and Macpherson 2011).

According to the current nomenclature, E. granulosus s. 1. circulating in Europe has been subdivided into E. granulosus sensu stricto ("sheep strain" and "buffalo strain", genotypes G1 and G3), Echinococcus equinus ("horse strain", G4), Echinococcus ortleppi ("cattle strain", G5) and Echinococcus canadensis ("camel strain", G6; "pig strain", G7; "two cervid strains", G8 and G10) (Romig et al. 2015). Human cystic echinococcosis is caused predominantly (approximately $90 \%$ 
of cases worldwide) by E. granulosus s. s., which has the most cosmopolitan distribution and is largely transmitted in areas with extensive sheep farming (Alvarez Rojas et al. 2014). That species is followed by E. canadensis (genotypes G6-G10), globally responsible for about $10 \%$ of human infections. Among the remaining species traditionally classified as E. granulosus sensu lato, only nine human infections with E. ortleppi (G5) and no infection with E. equinus (G4) have been reported to date (Alvarez Rojas et al. 2014; Grenouillet et al. 2014).

In Poland, in 2015, over 4500 cases of cystic echinococcosis in farm animals were recorded according to the report of the European Food Safety Authority (EFSA and ECDC 2016), and in $99.56 \%$ of those cases, pigs were the intermediate hosts. Only 0.43 and $0.01 \%$ of cases of cystic echinococcosis were recorded in sheep and cattle, respectively. All genotyped metacestodes originating from humans, domestic pigs and the European beaver belonged to the G7 genotype of E. canadensis (summarized in Cardona and Carmena 2013; Alvarez Rojas et al. 2014). In geographical terms, transmission of the G7 genotype is largely confined to a contiguous zone in central and eastern Europe including the Baltic region. No records about the circulation of highly pathogenic E. granulosus s. s. in Poland and/or neighboring countries are available so far.

The study was conducted to extend the knowledge about the genotype spectrum of Echinococcus granulosus tapeworms circulating in sheep, pigs and humans in Poland.

\section{Material and methods}

Sample collection Echinococcus protoscoleces were collected from the livers of naturally infected pigs (two isolates from the Masovian Voivodeship in central Poland) and sheep (one isolate from Podhale district in Lesser Poland Voivodeship in southern Poland). Three human samples were derived from surgically removed hydatid cysts from patient livers at the Department of General Transplant and Liver Surgery, Medical University of Warsaw (central Poland). Sheep and pig samples were frozen at $-20{ }^{\circ} \mathrm{C}$, subsequently defrosted and stored in $70 \%$ ethanol. Human samples were stored in $70 \%$ ethanol.

DNA extraction Fragments of ethanol-preserved hydatid cyst samples were dried at room temperature, homogenised and subjected to DNA isolation by the silica-guanidinium procedure (Boom et al. 1999).

DNA amplification and sequencing A gene fragment of cytochrome $c$ oxidase subunit 1 (coxl, $396 \mathrm{bp}$ ) was amplified with JB3/JB4.5 primers (Bowles et al. 1993) from mitochondrial DNA of all isolates. In the sheep isolate, a portion of the small subunit ribosomal RNA gene ( $r r n S, 372 \mathrm{bp}$ ) was amplified with P60/P375 primers (Dinkel et al. 1998). Amplified PCR products of both mitochondrial genes were then subjected to automated Sanger sequencing.

Sequence analysis The sequences of the coxl gene were compared to the reference sequences (Bowles et al. 1992) of E. granulosus (genotypes G1-G3), E. equinus (genotype G4), E. ortleppi (genotype G5) and E. canadensis (genotypes G6 and G7). The sequences of the mitochondrial small subunit rRNA were compared to the reference sequences (Dinkel et al. 2004; Busi et al. 2007) of E. granulosus s. s. (G1 and G3) and E. canadensis (G6 and G7). The multiple sequence alignments were performed using the CLC Main Workbench 7 software. Generated haplotypes were identified through BLASTn analysis. To distinguish synonymous and nonsynonymous mutations, EMBOSS transeq software for deriving protein sequences was used. The sequences reported in this paper were deposited in the GenBank database with the accession numbers KJ831062, KM191134, MF580386 and MF580387.

Morphological analysis Protoscoleces were mounted in Hoyer's medium (Cielecka et al. 2009) and pressure was applied to the coverslip to cause the hooks to lie flat. All measurements were taken by the same person (D. C.) using a calibrated eyepiece micrometer under oil immersion. The number of rostellar hooks, the length of the blades of large and small hooks and total length of the large and the small hooks were considered. The hooks were measured according to Ponce Gordo and Cuesta Bandera (1997). Only invaginated, viable protoscoleces were analysed.

\section{Results}

Based on the sequences the coxl gene fragment five isolates (2 from pigs and 3 from humans) were classified as bearing the G7 genotype. The isolate from sheep was identified as the G1 genotype based on the sequence of the fragments of coxl and $r r n S$ genes and herein was provisionally designated as G1A microvariant sensu Šnábel et al. (2009) (Table 1).

\section{$\operatorname{cox} 1$}

The sequence of the coxl gene of the isolate from sheep had the highest level of similarity to reference genotypes G1-G3 of $E$. granulosus s. s., with one substitution $(56 \mathrm{C} / \mathrm{T})$ compared to the reference G1 genotype, two substitutions $(66 \mathrm{~T} / \mathrm{C}$, $257 \mathrm{C} / \mathrm{T}$ ) compared to previously assigned G2 genotype, and three substitutions $(56 \mathrm{C} / \mathrm{T}, 66 \mathrm{C} / \mathrm{T}, 257 \mathrm{C} / \mathrm{T})$ compared to the G3 genotype. The non-synonymous nucleotide change with a 
Table 1 Previous available records of G1A microvariant of Echinococcus granulosus sensu stricto

\begin{tabular}{|c|c|c|c|}
\hline Region/countries & Host $(n)$ & GenBank accession numbers & References \\
\hline \multicolumn{4}{|l|}{ Africa } \\
\hline Algeria & Human (2) & KR349028 & Zait et al. (2016) \\
\hline Ethiopia & Sheep (3), cattle (1), camel (1) & $\mathrm{AB} 650531$ & Hailemariam et al. (2012) \\
\hline Morocco & Camel & EF367279 & \\
\hline Morocco & Cattle (2) & EF367280, EF367283 & \\
\hline Morocco & Goat & EF367281 & \\
\hline Morocco & Mule & EF367285 & \\
\hline Morocco & Sheep (2) & EF367282, EF367284 & \\
\hline Tunisia & Cattle (3), human (3), sheep (1) & & M'rad et al. (2005) \\
\hline Tunisia & Cattle (6), human (2), sheep (1) & & M'rad et al. (2010) \\
\hline Tunisia & Donkey (7), sheep (4), cattle (1) & KM014642 & Boufana et al. (2014) \\
\hline Tunisia & Human & KM014643 & Boufana et al. (2014) \\
\hline Tunisia & Sheep (2), wild boar (1) & KM014641 & Boufana et al. (2014) \\
\hline $\begin{array}{l}\text { Africa (country of origin } \\
\text { not known }\end{array}$ & Red-tailed guenon & JX068640 & Boufana et al. (2012) \\
\hline \multicolumn{4}{|l|}{ Asia } \\
\hline Armenia & Cattle (6) & $\begin{array}{l}\text { KX020338, KX020339, KX020344, } \\
\quad \text { KX020345, KX020368,KX020372 }\end{array}$ & \\
\hline Armenia & Goat & KX020377 & \\
\hline Armenia & Human (5) & $\begin{array}{l}\text { KX020337, KX020341, KX020359, } \\
\text { KX020365, KX020367 }\end{array}$ & \\
\hline Armenia & Sheep (8) & $\begin{array}{l}\text { KX020336, KX020357, KX020383, } \\
\text { KX020386, KX020388, KX020391, } \\
\text { KX020392, KX020402 }\end{array}$ & \\
\hline China, Qinghai province & Sheep (3) & AB491421 & Nakao et al. (2010) \\
\hline China, Xinjiang province & Human (2) & AB491439, AB491447 & Nakao et al. (2010) \\
\hline China, Xinjiang province & Human (3), dog (11) & DQ356877 & Bart et al. (2006) \\
\hline Kazakhstan & Dog & КT001396 & Boufana et al. (2015) \\
\hline Mongolia & Human & AB893246 & Ito et al. (2014) \\
\hline Mongolia & Human (2) & AB787546, AB787548 & \\
\hline Mongolia & Sheep (2) & AB787531, AB787538 & \\
\hline Russia (Altai Krai) & Human & AB688139 & Konyaev et al. (2012a) \\
\hline Russia (Novosibirsk Oblast) & Human & AB688140 & Konyaev et al. (2012a) \\
\hline \multicolumn{4}{|l|}{ Europe } \\
\hline Albania & Sheep & KU925433 & Kinkar et al. (2016) \\
\hline Austria & Human & AJ508019 & Obwaller et al. (2004) \\
\hline Bulgaria & Human & KY235681 & \\
\hline Greece & Sheep & KM245580 & \\
\hline Hungary & Human & JF690976 & Šnábel et al. (2016) \\
\hline Italy & Sheep (3) & & Busi et al. (2007) \\
\hline Moldova & Sheep (6), cattle (2) & KJ782437 & Umhang et al. (2014) \\
\hline Poland & Sheep & KJ831062 & this study \\
\hline Portugal & Sheep & HF947559 & Beato et al. (2013) \\
\hline Romania & Cattle & KU925431 & Kinkar et al. (2016) \\
\hline Russia (Permskiy Krai) & Sheep & AB777906 & Konyaev et al. (2013) \\
\hline Spain & Sheep & KU925419 & Kinkar et al. (2016) \\
\hline \multicolumn{4}{|l|}{ Middle East } \\
\hline Iran & Camel & JQ250814 & Yanagida et al. (2012) \\
\hline Iran & Camel & HM563013 & \\
\hline Iran & Dog & KP339046 & Gholami et al. (2016) \\
\hline Iran & Dog & JN604098 & Parsa et al. (2012) \\
\hline Iran & Goat & KR337820 & \\
\hline Iran & Sheep (11), cattle (7), human (6) & KP859560 & Farhadi et al. (2015) \\
\hline Iran & Human & AB677811 & Pezeshki et al. (2013) \\
\hline Iran & Human (2) & JQ250810, JQ250812 & Yanagida et al. (2012) \\
\hline Iran & Sheep & JQ219962 & \\
\hline Iran & Sheep & KP751431 & \\
\hline Iran & Sheep & HM563012 & \\
\hline Iran & Human & KM513627 & Sharbatkhori et al. (2016) \\
\hline Iran & Sheep & КT074944 & Sharbatkhori et al. (2016) \\
\hline Iran & Cattle & KT074945 & Sharbatkhori et al. (2016) \\
\hline Iran & Camel & KT074946 & Sharbatkhori et al. (2016) \\
\hline
\end{tabular}


Table 1 (continued)

\begin{tabular}{|c|c|c|c|}
\hline Region/countries & Host $(n)$ & GenBank accession numbers & References \\
\hline Iran & Sheep (3) & $\begin{array}{l}\text { JQ250809, JQ250811, } \\
\text { JQ250813 }\end{array}$ & Yanagida et al. (2012) \\
\hline Iran & Water buffalo (6) & HM130586-HM130591 & Pour et al. (2011) \\
\hline Iran & Cattle (2) & KT254113, КT254124 & \\
\hline Jordan & Sheep (2) & AB688599, AB688600 & Yanagida et al. (2012) \\
\hline Palestine & Sheep (2) & KC109657, KC109659 & Adwan et al. (2013) \\
\hline Turkey & Cattle (14) & $\begin{array}{l}\text { KU925358, KU925364, KU925370, } \\
\text { KU925372, KU925373, KU925376, } \\
\text { KU925378, KU925379, KU925384, } \\
\text { KU925385 KU925386, } \\
\text { KU925409-KU925411 }\end{array}$ & Kinkar et al. (2016) \\
\hline Turkey & Sheep (8) & $\begin{array}{l}\text { KU925385, KU925391, KU925392, } \\
\text { KU925401, KU925402, KU925404, } \\
\text { KU925405, KU925412 }\end{array}$ & Kinkar et al. (2016) \\
\hline Turkey & Human (2) & HQ717148 & Eryıldız and Șakru (2012) \\
\hline Turkey & Sheep & AJ508012 & Obwaller et al. (2004) \\
\hline Turkey & Sheep & KM100575 & \\
\hline Turkey & Cattle & EF689726 & Utuk et al. (2008) \\
\hline Turkey & Cattle (2) & EU178104 & Vural et al. (2008) \\
\hline Turkey & Human (2) & JF775379 & Šnábel et al. (2009) \\
\hline Turkey & Sheep & JF775380 & Šnábel et al. (2009) \\
\hline Turkey & Sheep & JN810793 & \\
\hline Turkey & Water buffalo (2) & HM598457, HM598459 & Beyhan and Umur (2011) \\
\hline \multicolumn{4}{|l|}{ South America } \\
\hline Argentina & Cattle & KX039951 & Laurimäe et al. (2016) \\
\hline Brazil & Sheep & HF947571 & Beato et al. (2013) \\
\hline
\end{tabular}

$n$ number of host specimens

thymine at position 56, which induces substitution of alanine with valine, is typical of the G2 genotype, but the remaining nucleotides of sheep isolate corresponded to the sequence pattern of the G1 genotype.

The coxl sequences obtained from human and swine isolates were identical to the reference sequence for genotype G7 of E. canadensis. Multiple sequence alignments are presented in Fig. 1.

\section{$\operatorname{rrnS}$}

The sequence of the $r r n S$ gene obtained from the sheep isolate had $100 \%$ homology with a G1 reference sequence, thus corroborating genotypic structure characteristic for E. granulosus s. s. G1.

\section{Morphological characteristics of protoscoleces}

The rostellar hook characteristics of protoscoleces of Polish sheep origin are shown in Table 2. Morphometrical data suggested that rostellar hooks in the examined sheep were apparently shorter than those previously measured from pig and humans in the same region of Europe (Poland and Ukraine), whereas a high similarity in hook sizes was found in relation to previously analysed sheep isolates from UK and Spain.

\section{Discussion}

The presented data provide the first evidence of the presence of autochthonous infection with E. granulosus s. s. in Poland,

Fig. 1 Alignment of variable sites in the partial coxl sequences (366 bp) with available sequences of related reference genotypes. $\mathrm{N}$ number of isolates detected for each variant, $\mathrm{S}$ sheep host, $\mathrm{P}$ pig host, $\mathrm{H}$ human host

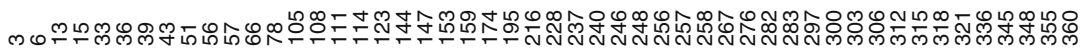

G1ref-DQ062857 T A A A G T T G T C G C G G T C G T G G G G C G G A G G G G G T T G A T G G G T G G A T T G A A G

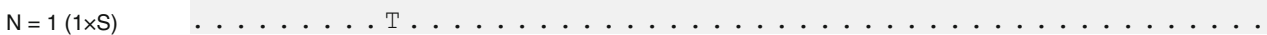

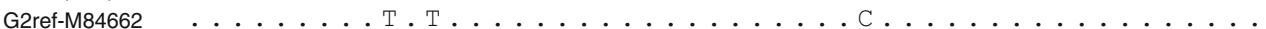

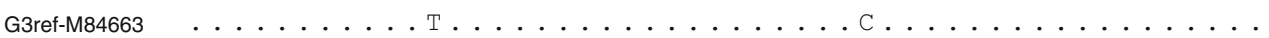
G4ref-M84664 . G. . A G. . G T.T.AAT.G. . . TATG.A.AA A G T.G.T. . TA. . T.AGGA G5ref-M84665.GGT..C.GTTTAA.TT...TT.GA.TACG.TG.ATAC.TT.TG.GG. G6refM84666 ..GT.G.TGTTT.A.T TAAA.TTT.GA.TA.C.TG.ATA...CCT..GGA G7ref-M84667 C.GT.G.TGTTT.A.T TAAA.T T T.GA.TA.C.TG.ATA...CCT..GGA $N=3(2 \times P, 1 \times H) \quad C \cdot G T \cdot G \cdot T G T T T \cdot A \cdot T T A A A \cdot T T T \cdot G A \cdot T A \cdot C \cdot T G \cdot A T A \ldots C C T \ldots G G A$ 
which was detected in a sheep metacestode. We classified the sheep isolate from Podhale district located in the southernmost region of Poland as belonging to E. granulosus s. s. G1 based on sequences of mitochondrial genes. Apart from that, three human isolates and two pig isolates derived from central Poland were identified as E. canadensis $\mathrm{G} 7$.

The finding of endemic E. granulosus s. s. infection in Poland is of epidemiological significance given that its cysts are often fertile in humans, and numerous findings indicate their increased infectivity (or pathogenicity) compared to other Echinococcus species (Romig et al. 2015). According to the European Union summary report, $0.20 \%$ of pigs were infected with E. granulosus s. 1. $(44,981 / 21,973,398)$ and $0.49 \%$ prevalence rate $(193 / 39,220)$ in sheep and goats was measured in 2015 during meat inspections at slaughterhouses (EFSA and ECDC 2016). Poland was ranked among the five EU countries exhibiting the highest number of animals infected with E. granulosus s. 1. in this report. Although the pig is a major intermediate host mediating transmission of $E$. granulosus in the country given the high overall number of these infected animals, the role of sheep as an effective intermediate host for E. granulosus s. s. should also be taken into account, considering the current G1 finding. For humans, in 2011-2015, among 181 recorded cases of human echinococcosis at least 53 were caused by E. granulosus s. 1. in Poland (Gołąb et al. 2016).

In E. granulosus s. 1. isolates from Poland subjected to genotyping, the G7 genotype of $E$. canadensis was initially documented in 38 pigs and five humans (Kędra et al. 1999). G7 genotype was also found in a European beaver originating from north-eastern Poland (Tkach et al. 2002). In surveys targeted to human CE infections, Pawłowski and Stefaniak (2003) reported 16 patients infected with G7 from the Poznan region in central-western Poland, as was also reported by Dybicz et al. (2013) for 30 patients from central Poland. This was followed by another report of Dybicz et al. (2015), documenting seven cases of G7-infected patients and two cases of G1-infected patients coming from central Poland. Nevertheless, the authors stated that patients may have been infected with E. granulosus s. s. G1 outside Poland (Kazakhstan and Turkey, respectively), and thus they cannot be unambiguously regarded as indigenous. Hydatid cysts recently isolated from a patient in south-eastern Poland had homologous sequences to E. canadensis G7 (Šnábel et al. 2016). Overall, a total of 62 autochthonous G7 human infections have thus been until now documented in Poland including this study, along with $40 \mathrm{G} 7$ pig infections, one G7 infection in the European beaver and one G1 infection in sheep presently recorded. According to our knowledge, E. granulosus from sheep were not genotyped to date in this country.

In central and northern Europe, E. granulosus s. s. (G1-G3 complex) is being detected only sporadically. Human autochthonous E. granulosus s. s. cases were recorded in Austria in two patients (Schneider et al. 2010) and in Hungary in one 
patient (Šnábel et al. 2016). In the latter human case originated from Békes county, the microvariant G1A identical to that seen in the present study was detected. Northward from Poland, E. granulosus s. s. G1 was recently identified in 4 (2.2\%) urban dogs in Estonia (Tartu city) in the Baltic region, although E. granulosus tapeworms are primarily transmitted in the country through sylvatic cycle, maintained by moose and wolves harbouring E. canadensis G8 and G10 genotypes (Laurimaa et al. 2015). In a part of Russia belonging to eastern Europe, three E. granulosus s. s. G1 cases were documented in a domestic cat from Saint Petersburg (Konyaev et al. 2012b), in a sheep from Permskiy Krai and in a human from the Republic of Bashkiria (Konyaev et al. 2013). Sheep farming strongly affects the distribution of E. granulosus s. $\mathrm{s}$ in Europe, although involvement of cattle and goats as intermediate hosts may also be considerable in some regions.

The G1A microvariant, which bears the substitution $\mathrm{C} / \mathrm{T}$ at position 56 relative to the common G1 type, commonly occurs in the southern Palearctic; we have found 206 records in GenBank entries and published articles with this sequence pattern worldwide (summarized list is in Table 1). According to the available data, the highest frequencies of this cosmopolitan G1A form were to date recorded in Asia and Africa, which account for 6.34\% (136/2143) and 9.03\% (47/ 436) of the total numbers of E. granulosus s. s.-genetically determined isolates in these continents. Interestingly, the frequency of G1A haplotype in Europe was 1.19\% (14/1172) in compiled data that is a markedly lower distribution rate than those estimated in Asia and Africa. In main intermediate hosts of E. granulosus s. s., sheep and cattle, the proportion of rarer haplotypes in European populations has decreased with the increased distance from the domestication centre in the Middle East (Rannamäe et al. 2016). A similar scenario has likely occurred in their Echinococcus parasites, in which a part of genetic diversity was lost during their past distribution along the Mediterranean shore with livestock hosts. A low occurrence of G1A in Europe would also partially explain the lack of this haplotype in South America where only two findings (accounting for $0.20 \%$ frequency, 2/997) were to date documented in sheep from Brazil and in cattle from Argentina (Beato et al. 2013; Laurimae et al. 2016). The vast majority of cattle and sheep was imported to South America since sixteenth century from Europe (Arelovich et al. 2011), where the G1A haplotype is not abundant. Also several imports of livestock from Australia performed since the beginning of the twentieth century (Haag et al. 2004) could not contribute to G1A dispersal in South America considering its absence in the former continent according to available data.

There is an apparent link of the G1A haplotype with a cluster affiliated to the Turkish haplotype Tur35, which was detected as one of the two central haplotypes in a recent paleogeographical study of G1 distribution in the Mediterranean region, conducted by screening 8274 bp of mtDNA (Kinkar et al. 2016). Sixteen of 18 haplotypes from Turkey, Albania and Romania identified in the above study as derived from Tur35 isolate, located in eastern Turkey in the vicinity of a domestication centre for the majority of livestock species, possessed the 36C/T nucleotide exchange. Dominance in a frequency of G1A findings in Africa over Europe might reflect earlier arrival and establishment of E. granulosus with sheep and other livestock in North Africa than in Europe, but it is more likely caused due to stochastic bottleneck events associated with founder effects.

The G1A variant was so far identified in 76 sheep, 50 cattle, 40 humans, 8 water buffaloes, 7 donkeys, 5 camels, 3 goats, 1 wild boar, 1 mule and 1 red-tailed guenon within intermediate hosts (Table 1). Humans are globally infected with G1A in similar proportions as major livestock intermediate hosts (sheep to humans ratio 1.9, cattle to humans ratio 1.25), compared to the overall figure derived from published G1 records, encompassing 1478 sheep, 1492 cattle and 929 human isolates (ratio sheep to humans 1.59 , cattle to humans ratio 1.61). Although a higher number of human G1A isolates was detected especially in comparison to cattle, differences in distributions of G1 and G1A genotypes in respective hosts are not yet statistically significant at $p<0.05$ (Fisher's exact test; $p=0.27$ for cattle/human comparisons, $p=0.43$ for sheep/human comparisons). Nucleotide substitutions seen in G1A genotype thus do not seemingly confer a higher virulence for this variant towards humans and do not present any epidemiological relevance.

Results obtained from rostellar hook morphology of protoscoleces from sheep of Polish origin corroborated our genetic determination in measuring shorter hooks than those from pig cysts from Poland and Ukraine (referenced data obtained from Eckert et al. 1997; Yemets 2003). The hooks were also shorter than those from humans in Poland and Ukraine (referenced by Cielecka et al. 2005) that had been later genetically confirmed as belonging to the "pig strain" (attributable to E. canadensis G7). Size differences were not so striking compared to pig isolates of Spanish origin (provided by Ponce Gordo and Cuesta Bandera 1997) in some hook characteristics; however, Spanish isolates could contain a mixture of G7 and G1 genotypes considering later reports on pig findings in the country (González et al. 2002; Daniel Mwambete et al. 2004).

The hooks had similar size to those originating from Spain and UK in the material obtained from sheep (Spain, UK) and humans (Spain) (referenced by Thompson et al. 1984; Kumaratilake et al. 1986; Ponce Gordo and Cuesta Bandera 1997). The cysts isolated from Spanish patients contained "sheep-cattle strain" (sensu Ponce Gordo and Cuesta Bandera 1997) that is now presumed to be E. granulosus s. s. given the territory and host concerned, which applies also for morphologically examined sheep samples from the UK by the above-mentioned authors. Nevertheless, data of rostellar 
hook morphology has to be interpreted with some caution given the effect of environmental factors, particularly host species (Hobbs et al. 1990).

High endemicity of human CE is being reported from areas with frequent transmission of $E$. granulosus s. s. The finding of infectious E. granulosus s. s. G1 in Poland, thus poses a threat to public health and may be relevant to the implementation of hydatid control in the country. As dosing regimes of dogs in control programmes are locally designed for the shorter development time of E. canadensis G7 (approx. 34 days p. i.), further measures should take into consideration simultaneous occurrence of more slowly developing Echinococcus s. s. with average maturation rate 45 days p. i. (Kumaratilake et al. 1983; Eckert et al. 1993). In the epidemiological situation in Poland characterized by intense transmission of $E$. canadensis $\mathrm{G} 7$ in domestic animals, a sporadic occurrence of E. granulosus s. s. should also be taken in account. Further metacestode samples should be analyzed from a variety of intermediate hosts (with special attention paid to sheep and humans) in concerned regions to provide a more detailed picture about the genotypic diversity of $E$. granulosus in Poland.

Acknowledgements The research was carried out in the framework of the scientific cooperation between the Medical University of Warsaw and I. I. Schmalhausen Institute of Zoology of the National Academy of Sciences of Ukraine. A part of the study was supported by the Scientific Grant Agency VEGA (project no. 2/0162/17). We would like to thank dr Aleksander Masny from the National Institute of Public Health - National Institute of Hygiene (Warsaw) who offered unflagging support and wise advice.

Open Access This article is distributed under the terms of the Creative Commons Attribution 4.0 International License (http:// creativecommons.org/licenses/by/4.0/), which permits unrestricted use, distribution, and reproduction in any medium, provided you give appropriate credit to the original author(s) and the source, provide a link to the Creative Commons license, and indicate if changes were made.

\section{References}

Adwan G, Adwan K, Bdir S, Abuseir S (2013) Molecular characterization of Echinococcus granulosus isolated from sheep in Palestine. Exp Parasitol 134:195-199. https://doi.org/10.1016/j.exppara.2013. 03.024

Alvarez Rojas CA, Romig T, Lightowlers MW (2014) Echinococcus granulosus sensu lato genotypes infecting humans - review of current knowledge. Int J Parasitol 44:9-18. https://doi.org/10.1016/j. ijpara.2013.08.008

Arelovich HM, Bravo DR, Martínez MF (2011) Development, characteristics, and trends for beef cattle production in Argentina. Anim Front 1:37-45. https://doi.org/10.2527/af.2011-0021

Bart JM, Abdukader M, Zhang YL, Lin RY, Wang YH, Nakao M, Ito A, Craig PS, Piarroux R, Vuitton DA, Wen H (2006) Genotyping of human cystic echinococcosis in Xinjiang, PR China. Parasitology 133:571-579. https://doi.org/10.1017/S0031182006000734

Beato S, Parreira R, Roque C, Gonçalves M, Silva L, Maurelli MP, Cringoli G, Grácio MA (2013) Echinococcus granulosus in
Portugal: the first report of the G7 genotype in cattle. Vet Parasitol 198:235-239. https://doi.org/10.1016/j.vetpar.2013.08.021

Beyhan YE, Umur Ș (2011) Molecular characterization and prevalence of cystic echinococcosis in slaughtered water buffaloes in Turkey. Vet Parasitol 181:174-179. https://doi.org/10.1016/j. vetpar.2011.04.038

Boom R, Sol C, Beld M, Weel J, Goudsmit J, Wertheim-van Dillen P (1999) Improved silica-guanidiniumthiocyanate DNA isolation procedure based on selective binding of bovine alpha-casein to silica particles. J Clin Microbiol 37:615-619

Boufana B, Lahmar S, Rebai W, Ben Safta Z, Jebabli L, Ammar A, Kachti M, Aouadi S, Craig PS (2014) Genetic variability and haplotypes of Echinococcus isolates from Tunisia. Trans R Soc Trop Med Hyg 108:706-714. https://doi.org/10.1093/trstmh/tru138

Boufana B, Lett W, Lahmar S, Griffiths A, Jenkins DJ, Buishi I, Engliez SA, Alrefadi MA, Eljaki AA, Elmestiri FM, Reyes MM, Pointing S, Al-Hindi A, Torgerson PR, Okamoto M, Craig PS (2015) Canine echinococcosis: genetic diversity of Echinococcus granulosus sensu stricto (s. s.) from definitive hosts. J Helminthol 89:689-698. https:// doi.org/10.1017/S0022149X15000395

Boufana B, Stidworthy MF, Bell S, Chantrey J, Masters N, Unwin S, Wood R, Lawrence RP, Potter A, McGarry J, Redrobe S, Killick R, Foster AP, Mitchell S, Greenwood AG, Sako Y, Nakao M, Ito A, Wyatt K, Lord B, Craig PS (2012) Echinococcus and Taenia spp. from captive mammals in the United Kingdom. Vet Parasitol 190: 95-103. https://doi.org/10.1016/j.vetpar.2012.05.023

Bowles J, Blair D, McManus DP (1992) Genetic variants within the genus Echinococcus identified by mitochondrial DNA sequencing. Mol Biochem Parasitol 54:165-173

Bowles J, Hope M, Tiu WU, Liu X, McManus DP (1993) Nuclear and mitochondrial genetic markers highly conserved between Chinese and Philippine Schistosoma japonicum. Acta Trop 55:217-229

Busi M, Snábel V, Varcasia A, Garippa G, Perrone V, De Liberato C, D'Amelio S (2007) Genetic variation within and between G1 and G3 genotypes of Echinococcus granulosus in Italy revealed by multilocus DNA sequencing. Vet Parasitol 150:75-83. https://doi. org/10.1016/j.vetpar.2007.09.003

Cardona GA, Carmena D (2013) A review of the global prevalence, molecular epidemiology and economics of cystic echinococcosis in production animals. Vet Parasitol 192:10-32. https://doi.org/10. 1016/j.vetpar.2012.09.027

Cielecka D, Gierczak A, Michałowicz B, Salamatin RV (2005) Comparison of morphology of rostellar hooks of Echinococcus granulosus larvae in human patients from Poland, Ukraine and Kazakhstan. Vestn Zool Suppl 19(2):354-356 (in Ukrainian)

Cielecka D, Salamatin R, Garbacewicz A (2009) Usage of the Hoyer's medium for diagnostics and morphological studies of some parasites. Wiad Parazytol 55:265-270 (in Polish)

Daniel Mwambete K, Ponce-Gordo F, Cuesta-Bandera C (2004) Genetic identification and host range of the Spanish strains of Echinococcus granulosus. Acta Trop 91:87-93. https://doi.org/10.1016/j. actatropica.2004.04.001

Dinkel A, Njoroge EM, Zimmermann A, Wälz M, Zeyhle E, Elmahdi IE, Mackenstedt U, Romig TA (2004) PCR system for detection of species and genotypes of the Echinococcus granulosus-complex, with reference to the epidemiological situation in eastern Africa. Int J Parasitol 34:645-653

Dinkel A, von Nickisch-Rosenegk M, Bilger B, Merli M, Lucius R, Romig T (1998) Detection of Echinococcus multilocularis in the definitive host: coprodiagnosis by PCR as an alternative to necropsy. J Clin Microbiol 36:1871-1876

Dybicz M, Borkowski PK, Dąbrowska J, Chomicz L (2015) Cases of Echinococcus granulosus sensu stricto isolated from polish patients: imported or indigenous? Biomed Res Int 2015:728321. https://doi. org $/ 10.1155 / 2015 / 728321$ 
Dybicz M, Gierczak A, Dąbrowska J, Rdzanek L, Michałowicz B (2013) Molecular diagnosis of cystic echinococcosis in humans from central Poland. Parasitol Int 62:364-367. https://doi.org/10.1016/j. parint.2013.03.005

Eckert J, Thompson RCA, Lymbery AJ, Pawlowski ZS, Gottstein B, Morgan UM (1993) Further evidence for the occurrence of a distinct strain of Echinococcus granulosus in European pigs. Parasitol Res 79:42-48. https://doi.org/10.1007/BF00931216

EFSA (European Food Safety Authority) and ECDC (European Centre for Disease Prevention and Control) (2016) The European Union summary report on trends and sources of zoonoses, zoonotic agents and food-borne outbreaks in 2015. EFSA J 14:e04634. https://doi. org/10.2903/j.efsa.2016.4634

Eryıldız C, Şakru N (2012) Molecular characterization of human and animal isolates of Echinococcus granulosus in the Thrace Region, Turkey. Balkan Med J 29:261-267. https://doi.org/10.5152/ balkanmedj.2012.072

Farhadi M, Fazaeli A, Haniloo A (2015) Genetic characterization of livestock and human hydatid cyst isolates from northwest Iran, using the mitochondrial cox1 gene sequence. Parasitol Res 114:4363-4370. https://doi.org/10.1007/s00436-015-4673-y

Gholami S, Jahandar H, Abastabar M, Pagheh A, Mobedi I, Sharbatkhori M (2016) Echinococcus granulosus sensu stricto in dogs and jackals from Caspian Sea Region, Northern Iran. Iran J Parasitol 11:186-194

Gołąb E, Czarkowski M, Sałamatin R, Sadkowska-Todys M (2016) Infections with Echinococcus spp. in the epidemiological records of Poland. Ann Parasitol 62(Supplement):80

González LM, Daniel-Mwambete K, Montero E, Rosenzvit MC, McManus DP, Gárate T, Cuesta-Bandera C (2002) Further molecular discrimination of Spanish strains of Echinococcus granulosus. Exp Parasitol 102:46-56

Grenouillet F, Umhang G, Arbez-Gindre F, Mantion G, Delabrousse E, Millon L, Boue F (2014) Echinococcus ortleppi infections in humans and cattle, France. Emerg Infect Dis 20:2100-2102. https://doi.org/10.3201/eid2012.140641

Haag KL, Ayala FJ, Kamenetzky L, Gutierrez AM, Rosenzvit M (2004) Livestock trade history, geography, and parasite strains: the mitochondrial genetic structure of Echinococcus granulosus in Argentina. J Parasitol 90:234-239. https://doi.org/10.1645/ GE-173R

Hailemariam Z, Nakao M, Menkir S, Lavikainen A, Yanagida T, Okamoto M, Ito A (2012) Molecular identification of unilocular hydatid cysts from domestic ungulates in Ethiopia: implications for human infections. Parasitol Int 61:375-377. https://doi.org/10. 1016/j.parint.2012.01.007

Hobbs RP, Lymbery AJ, Thompson RC (1990) Rostellar hook morphology of Echinococcus granulosus (Batsch, 1786) from natural and experimental Australian hosts, and its implications for strain recognition. Parasitology 101:273-281

Ito A, Dorjsuren T, Davaasuren A, Yanagida T, Sako Y, Nakaya K, Nakao M, Bat-Ochir O-E, Ayushkhuu T, Bazarragchaa N, Gonchigsengee N, Li T, Agvaandaram G, Davaajav A, Boldbaatar C, Chuluunbaatar G (2014) Cystic echinococcoses in Mongolia: molecular identification, serology and risk factors. PLoS Negl Trop Dis 8:e2937. https:// doi.org/10.1371/journal.pntd.0002937

Kędra AH, Świderski Z, Tkach VV, Dubinský P, Pawłowski Z, Stefaniak J, Pawlowski J (1999) Genetic analysis of Echinococcus granulosus from humans and pigs in Poland, Slovakia and Ukraine. A multicenter study. Acta Parasitol 44:248-254

Kinkar L, Laurimäe T, Simsek S, Balkaya I, Casulli A, Manfredi MT, Ponce-Gordo F, Varcasia A, Lavikainen A, González LM, Rehbein S, Van Der Giessen J, Sprong H, Saarma U (2016) High-resolution phylogeography of zoonotic tapeworm Echinococcus granulosus sensu stricto genotype G1 with an emphasis on its distribution in
Turkey, Italy and Spain. Parasitology 143:1790-1801. https://doi. org/10.1017/S0031182016001530

Konyaev SV, Yanagida T, Ingovatova GM, Shoikhet YN, Nakao M, Sako Y, Bondarev AY, Ito A (2012a) Molecular identification of human echinococcosis in the Altai region of Russia. Parasitol Int 61:711714. https://doi.org/10.1016/j.parint.2012.05.009

Konyaev SV, Yanagida T, Ivanov MV, Ruppel VV, Sako Y, Nakao M, Ito A (2012b) The first report on cystic echinococcosis in a cat caused by Echinococcus granulosus sensu stricto (G1). J Helminthol 86: 391-394. https://doi.org/10.1017/S0022149X1100054X

Konyaev SV, Yanagida T, Nakao M, Ingovatova GM, Shoykhet YN, Bondarev AY, Odnokurtsev VA, Loskutova KS, Lukmanova GI, Dokuchaev NE, Spiridonov S, Alshinecky MV, Sivkova TN, Andreyanov ON, Abramov SA, Krivopalov AV, Karpenko SV, Lopatina NV, Dupal TA, Sako Y, Ito A (2013) Genetic diversity of Echinococcus spp. in Russia. Parasitology 140:1637-1647. https:// doi.org/10.1017/S0031182013001340

Kumaratilake LM, Thompson RC, Dunsmore JD (1983) Comparative strobilar development of Echinococcus granulosus of sheep origin from different geographical areas of Australia in vivo and in vitro. Int J Parasitol 13:151-156. https://doi.org/10.1016/0020-7519(83) 90005-X

Kumaratilake LM, Thompson RC, Eckert J (1986) Echinococcus granulosus of equine origin from different countries possess uniform morphological characteristics. Int J Parasitol 16:529-540

Laurimaa L, Davison J, Süld K, Plumer L, Oja R, Moks E, Keis M, Hindrikson M, Kinkar L, Laurimäe T, Abner J, Remm J, Anijalg P, Saarma U (2015) First report of highly pathogenic Echinococcus granulosus genotype G1 in dogs in a European urban environment. Parasit Vectors 8:182. https://doi.org/10.1186/s13071-015-0796-3

Laurimäe T, Kinkar L, Andresiuk V, Haag KL, Ponce-Gordo F, AcostaJamett G, Garate T, Gonzàlez LM, Saarma U (2016) Genetic diversity and phylogeography of highly zoonotic Echinococcus granulosus genotype G1 in the Americas (Argentina, Brazil, Chile and Mexico) based on 8279 bp of mtDNA. Infect Genet Evol 45: 290-296. https://doi.org/10.1016/j.meegid.2016.09.015

M'rad S, Filisetti D, Oudni M, Mekki M, Belguith M, Nouri A, Sayadi T, Lahmar S, Candolfi E, Azaiez R, Mezhoud H, Babba H (2005) Molecular evidence of ovine (G1) and camel (G6) strains of Echinococcus granulosus in Tunisia and putative role of cattle in human contamination. Vet Parasitol 129:267-272. https://doi.org/ 10.1016/j.vetpar.2005.02.006

M'rad S, Oudni-M'rad M, Filisetti D, Mekki M, Nouri A, Sayadi T, Candolfi E, Azaiez R, Mezhoud H, Babba H (2010) Molecular identification of Echinococcus granulosus in Tunisia: first record of the buffalo strain (G3) in human and bovine in the country. Open Vet Sci J 4:27-30. https://doi.org/10.2174/ 1874318801004010027

Nakao M, Li T, Han X, Ma X, Xiao N, Qiu J, Wang H, Yanagida T, Mamuti W, Wen H, Moro PL, Giraudoux P, Craig PS, Ito A (2010) Genetic polymorphisms of Echinococcus tapeworms in China as determined by mitochondrial and nuclear DNA sequences. Int J Parasitol 40:379-385. https://doi.org/10.1016/j. ijpara.2009.09.006

Obwaller A, Schneider R, Walochnik J, Gollackner B, Deutz A (2004) Echinococcus granulosus strain differentiation based on sequence heterogeneity in mitochondrial genes of cytochrome c oxidase- 1 and NADH dehydrogenase-1. Parasitology 128:569-575. https://doi. org/10.1017/S0031182004004871

Parsa F, Fasihi Harandi M, Rostami S, Sharbatkhori M (2012) Genotyping Echinococcus granulosus from dogs from Western Iran. Exp Parasitol 132:308-312. https://doi.org/10.1016/j.exppara. 2012.07.010

Pawłowski ZS, Stefaniak J (2003) Cystic echinococcosis (CE) in the Poznan region in the years 1990-2000. Przegl Epidemiol 57:579_ 586 (in Polish) 
Pezeshki A, Akhlaghi L, Sharbatkhori M, Razmjou E, Oormazdi H, Mohebali M, Meamar AR (2013) Genotyping of Echinococcus granulosus from domestic animals and humans from Ardabil Province, northwest Iran. J Helminthol 87:387-391. https://doi. org/10.1017/S0022149X1200051X

Ponce Gordo F, Cuesta Bandera C (1997) Differentiation of Spanish strains of Echinococcus granulosus using larval rostellar hook morphometry. Int J Parasitol 27:41-49

Pour AA, Hosseini SH, Shayan P (2011) Comparative genotyping of Echinococcus granulosus infecting buffalo in Iran using cox1 gene. Parasitol Res 108:1229-1234. https://doi.org/10.1007/s00436-0102170-x

Rannamäe E, Lõugas L, Niemi M, Kantanen J, Maldre L, Kadõrova N, Saarma U (2016) Maternal and paternal genetic diversity of ancient sheep in Estonia from the Late Bronze Age to the post-medieval period and comparison with other regions in Eurasia. Anim Genet 47:208-218. https://doi.org/10.1111/age.12407

Romig T, Ebi D, Wassermann M (2015) Taxonomy and molecular epidemiology of Echinococcus granulosus sensu lato. Vet Parasitol 213(3/4):76-84. https://doi.org/10.1016/j.vetpar.2015.07.035

Schneider R, Gollackner B, Schindl M, Tucek G, Auer H (2010) Echinococcus canadensis G7 (pig strain): An underestimated cause of cystic echinococcosis in Austria. Am J Trop Med Hyg 82:871874. https://doi.org/10.4269/ajtmh.2010.09-0639

Sharbatkhori M, Tanzifi A, Rostami S, Rostami M, Fasihi Harandi M (2016) Echinococcus granulosus sensu lato genotypes in domestic livestock and humans in Golestan province, Iran. Rev Inst Med Trop Sao Paulo 58:38. https://doi.org/10.1590/S1678-9946201658038

Šnábel V, Altintas N, D'Amelio S, Nakao M, Romig T, Yolasigmaz A, Gunes K, Turk M, Busi M, Hüttner M, Sevcová D, Ito A, Dubinský P (2009) Cystic echinococcosis in Turkey: genetic variability and first record of the pig strain (G7) in the country. Parasitol Res 105: 145-154. https://doi.org/10.1007/s00436-009-1376-2

Šnábel V, Kuzmina T, Cavallero S, D’Amelio S, Georgescu SO, Szénási Z, Cielecka D, Sałamatin R, Yemets A, Kucsera I (2016) A molecular survey of Echinococcus granulosus sensu lato in central-eastern Europe. Open Life Sci 11:524-532. https://doi.org/10.1515/biol2016-0066
Thompson RC, Kumaratilake LM, Eckert J (1984) Observations on Echinococcus granulosus of cattle origin in Switzerland. Int J Parasitol 14:283-291

Tkach VV, Świderski Z, Drozdz J, Demiaszkiewicz AW (2002) Molecular identification of Echinococcus granulosus from wild European beaver, Castor fiber (L.) from North-Eastern Poland. Acta Parasitol 47:173-176

Torgerson PR, Macpherson CNL (2011) The socioeconomic burden of parasitic zoonoses: Global trends. Vet Parasitol 182:79-95. https:// doi.org/10.1016/j.vetpar.2011.07.017

Umhang G, Chihai O, Boué F (2014) Molecular characterization of Echinococcus granulosus in a hyperendemic European focus, the Republic of Moldova. Parasitol Res 113:4371-4376. https://doi.org/ 10.1007/s00436-014-4112-5

Utuk AE, Simsek S, Koroglu E, McManus DP (2008) Molecular genetic characterization of different isolates of Echinococcus granulosus in east and southeast regions of Turkey. Acta Trop 107:192-194. https://doi.org/10.1016/j.actatropica.2008.05.026

Vural G, Baca AU, Gauci CG, Bagci O, Gicik Y, Lightowlers MW (2008) Variability in the Echinococcus granulosus cytochrome C oxidase 1 mitochondrial gene sequence from livestock in Turkey and a reappraisal of the G1-3 genotype cluster. Vet Parasitol 154:347-350. https://doi.org/10.1016/j.vetpar.2008.03.020

Yanagida T, Mohammadzadeh T, Kamhawi S, Nakao M, Sadjjadi SM, Hijjawi N, Abdel-Hafez SK, Sako Y, Okamoto M, Ito A (2012) Genetic polymorphisms of Echinococcus granulosus sensu stricto in the Middle East. Parasitol Int 61:599-603. https://doi.org/10. 1016/j.parint.2012.05.014

Yemets OM (2003) Strain membership of Echinococcus granulosus in northern-eastern part of Ukraine and the peculiarities of its circulation in conditions of the region. Dissertation, Schmalhausen Institute of Zoology, Kyiv

Zait H, Kouidri M, Grenouillet FE, Umhang G, Millon L, Hamrioui B, Grenouillet F (2016) Molecular characterization of Echinococcus granulosus sensu stricto and Echinococcus canadensis in humans and livestock from Algeria. Parasitol Res 115:2423-2431. https:// doi.org/10.1007/s00436-016-4994-5 